\title{
Editorial Introduction: Becoming Ecofeminisms / Devenirs écoféministes
}

\author{
Astrida Neimanis and Christiane Bailey
}

What ever happened to ecofeminism? The answer is of course nothing, and everything. Even though ecofeminism may be sometimes (too closely) associated with a "hippier" time of Earth Mothers, green goddesses and "babes in the woods" (see Gaard "Misunderstanding"), ecofeminism constitutes a lively, contemporary practice and theory. This area of research and action continues to offer critical insights into the ways that sexism, heteronormativity, racism, colonialism, ableism, speciesism and environmental degradation all participate in interlocking logics of domination (see Adams and Gruen "Groundwork"). Indeed, as recognition of climate change, biodiversity loss, and other "Anthropocenic" power plays builds, ecofeminism may be more relevant than ever.

But importantly, in a paraphrase of Luce Irigaray, ecofeminism is "not one." While ecofeminism has not gone away, nor is it static. It continues to develop, not least, because the world that ecofeminism responds to is also changing. Changing as well is the world of feminist theory and scholarship, and these developments also nuance and sharpen ecofeminist analyses - while also opening new paths for solidarity and articulation. The plurality of ecofeminisms, however, is not only a question of "progress." Ecofeminism has always been multiple. While accounts of its genealogy may most often attribute this neologism to Francoise D'Eaubonne in 1974, scholars and practitioners nonetheless continue to tell diverse stories about ecofeminism's activist origins, its theoretical debts and scholarly alignments, and its political and ethical priorities. Ecofeminism-like any other area of scholarship -is always writing its own history. And, in the words of one of this Special Issue's contributors, Christina Holmes, such "genealogies shape not only how we understand our history, but also our present and future."

Tracing ecofeminism's movements is thus always descriptive but also potentially normative, and exclusionary. At the same time, boundary work, and the retelling of ecofeminism's story in new ways, can also be generative. Ultimately, then, we believe that this plurality is not a problem, but rather one of ecofeminism's strengths, and engines. This 
admission may give you a clue to the strange grammar of this Special Issue's title. In calling it "Becoming Ecofeminisms" we hoped to evoke a sense of both this plurality and continual unfolding-forward and back. Both grammatically and practially, "ecofeminism" resists a precise pinning down. Our goal for this Special Issue was to capture some of this plurality (not least, through a bilingual and bicultural interpretation of the themes), as well as some of this refusal to stay still (as our choice of water for our cover image might also indicate). We were interested in new takes on how ecofeminism might be understood, interpreted and enacted, both historically and in the present. In doing so, we wondered, how might we also envision ecofeminism's bold futures?

The English-language essays included in this Special Issue look to ecofeminism's alliances with other areas of scholarship and practice, and consider how these affinities - even if not entirely recognized or successful - can open up new directions for ecofeminisms to come. Christina Holmes's paper, "Sacred Genealogies: Spiritualities, Materiality and the Limits of Western Feminist Theoretical Frames" reviews what we might call a certain rise, fall, and resuscitation of ecofeminism within feminist studies, particularly in relation to the status of spirituality. Holmes' insightful analysis comments on the ways in which a refound acknowledgement of ecofeminism within sustainable development studies and the so-called feminist new materialisms has depended on the disavowal of a spirituality that in some cases has been crucial to ecofeminist practical and theoretical developments. Of particular concern to Holmes are Chicana feminist theorists and artists for whom spirituality is central. In this case, an evacuation of spirituality from ecofeminism within dominant Western feminist frames has meant an inability to focus on the important contributions of Chicana theorists and artists as precisely ecofeminist - and ecofeminist in ways perhaps even more radical and transformative than dominant versions of ecofeminism might posit, as evidenced in Holmes's analysis of artist Amalia MesaBaines installation work. Holmes' essay thus asks a number of important questions: first of all, how might spirituality not only be accommodated within but in fact recognised as a condition of possibility for (some) ecofeminisms? And perhaps even more (affirmatively) troubling: how might this interrupt some of ecofeminism's latest articulations that take rational development and/or empirical scientific study as their justification? As Holmes astutely notes, some of the ways in which we tell the story of ecofeminism dangerously risk "prop[ping] up a progress narrative of feminist theory that celebrates socialist and developmentoriented feminisms as smarter and more evolved" than spiritual orientations. Implicit in her questions, then, are provocations about the need for ecofeminism to continue to decolonise the stories it tells about itself. 
The second Engligh-language essay takes up ecofeminism's relation to some of these 'new' alignments more explicitly. Miriam Tola's paper, "Composing with Gaia: Isabelle Stengers and the Feminist Politics of the Earth" seeks to articulate the work of philosopher of science Isabelle Stengers, and in particular, her reworking of the figure of Gaia, with an ecofeminist orientation. Tola characterizes Stengers' view of Gaia, or the living planet, as "an assemblage of forces largely indifferent to human reasons and projects." Importantly, Tola suggests, Stengers' Gaia opens for us a way to think about the more-than-human as both in excess of us humans, but also at the same time inseparable from us. This concept thus gives us a way to disrupt the fantasy of human exceptionalism that goes hand in hand with our current dominant narratives of the Anthropocene. Ecofeminism enters Tola's analysis as one of the keys for interpreting Stengers' Gaia. Tola invites us to reconsider the relationship between ecofeminists, who (in Tola's account at least) focus on critiques of our dominant political economy and its enclosure of social reproduction and resourcing of "nature," and Deleuzian feminists, who are interested in forces that are "more than human." This reconsideration enables us to flesh out Stengers' image of Gaia as refusing the imperative to choose between planetary forces and anthropogenic ones as agents of our current ecological predicaments, and concomitantly to reject the image of a universal "Man" that orients current discourse on the Anthropocene. Instead, "composing with Gaia" demands our acknowledgement of the many earthly forces that world our current situation, in their crucially differently situated ways. Tola does not suggest that the "art of composition" is an easy one. It is quite the opposite, presenting us "with the enormous challenge of cultivating conviviality and endurance vis-à-vis neoliberal dispossession." It is here, however, that we see how a consideration of ecofeminism's echoes in and potential solidarities with other kinds of feminist thought propose no less than a different kind of "feminist politics of the earth."

La contribution en langue française de Jeanne Burgart Goutal analyse comment des phénomènes en apparence aussi hétérogènes que l'anthropocentrisme, l'androcentrisme et le rationalisme peuvent former un même «système » ou « matrice » de domination, comme le soutiennent plusieurs écoféministes. Elle développe la thèse selon laquelle il existe des liens entre diverses formes d'oppressions humaines et la domination des humains sur les animaux et la nature en reliant cette hypothèse à la notion de « carno-phallogocentrisme » développée par Jacques Derrida. Le carnophallogocentrisme nomme les fondements carnivore, misogyne et logocentriste de la tradition occidentale. Le «carnivorisme » désigne le fond zoocide et écocide des civilisations en guerre perpétuelle contre ce qu'elles appellent «l'animal » et réfère à la fois aux dimensions littérales et symboliques que prend la domination concrète des êtres humains sur les autres animaux et la supériorité idéologique de l'«humain» sur 
1'《animal ». L' « humanité » se construit par opposition et négation de l'« animalité »- à la fois en nous (corps, émotions, tendances, besoins, etc.) et hors de nous (l'immense variété des animaux qui partagent la planète avec nous). Le "phallogocentrisme » désigne l'association entre androcentrisme et rationalisme qui mène à penser l'humain sur le modèle du mâle et à ériger le logos en faculté souveraine scellant ainsi le «mariage de la raison et de la domination » (Plumwood). Cette «logique de la domination » mène à une vision dualiste, hiérarchique et suprématiste du monde en posant la supériorité supposée naturellement juste de la raison sur les émotions, de l'esprit sur le corps, de l' « humain » sur l' « animal », du « civilisé » sur le «sauvage», et, bien entendu, des hommes sur les femmes. Les écoféministes ne visent pas à identifier une lutte fondamentale (contre le patriarcat, le capitalisme ou l'anthropocentrisme) pouvant résoudre toutes les autres, mais à comprendre comment les diverses formes d'oppressions sont reliées et se renforcent les unes les autres. Loin d'une relation causale linéaire, il s'agirait plutôt d'une forme de «causalité circulaire » entre les diverses formes d'oppressions qui se nourrissent mutuellement. En identifiant comment le spécisme alimente le racisme et le colonialisme ou comment l'androcentrisme et la suprématie blanche renforcent l'anthropocentrisme et la suprématie humaine, on comprend mieux l'importance de combattre simultanément la «logique de la domination»dans la variété de ces formes.

Finalement, la contribution en langue anglaise de Marie-Anne Casselot offre une étude comparative de l'écoféminisme et du nouveau matéralisme en y décelant à la fois des liens théoriques communs et des points de tension. Le tournant néo-matérialiste se dessinait chez certaines écoféministes dans leur critique des dualismes (particulièrement du dualisme nature/culture et humain/non-humain), dans leur forte interdisciplinarité, dans leur suspicion envers les principes moraux abstraits et leur volonté de porter attention aux réalités matérielles à partir desquelles émergent nos pratiques éthiques et politiques et dans leur attention portée à la corporéité et aux relations matérielles, biologiques, bactériologiques, chimiques, écologiques, etc. Les différents écoféminismes visent à leurs manières à « recoudre le monde » (selon le titre de l'anthologie de Irene Diamond et Gloria Orenstein, Reweaving the World), à le « retisser » en articulant ensemble le biologique, le matériel et le culturel. Les dimensions éthiques et politiques sont cependant plus explicites chez les écoféministes que chez les nouvelles matérialistes où les réflexions sont principalement d'ordre épistémologique et ontologique. L'écoféminisme et le nouveau matérialisme se distinguent plus nettement selon Casselot sur les questions reliées à la technologie, à l'agentivité, à l'anthropocentrisme ainsi qu'au débat essentialisme/constructivisme. S'il est commun chez les écoféministes de penser l'agentivité et la corporéité au-delà de la compréhension étroitement anthropocentriste et rationaliste 
qu'en ont typiquement fait les traditions philosophiques occidentales, le nouveau matérialisme va beaucoup plus loin en reconnaissant une forme d'agentivité non seulement aux animaux autrement qu'humains ou même aux organismes vivants, mais également à la matière inorganique et aux objets fabriqués. En tant que retour à la matérialité du monde et des corps, le nouveau matérialisme tel qu'il se développe chez Braidotti, Grosz, Barad, Colebrook, Bennett, Dolphijn et van der Tuin a également un rapport plus positif envers la technologie qui est souvent la cible des écoféministes qui l'accusent de nous distancer du monde naturel. L'analyse comparative entre les différents écoféminismes et le nouveau matéralisme menée par Casselot est d'autant plus importante en raison du fait que, hormis Stacy Alaimo et Susan Hekman qui reconnaissent explicitement l'héritage de l'écoféminisme dans Material Feminisms, peu d'écrits appartenant au courant du nouveau matérialisme entrent en dialogue avec l'écoféminisme malgré leurs nombreux traits communs.

Les contributions regroupées dans ce numéro sur les «Devenirs écoféministes » rappellent que l'écoféminisme n'existe que comme pluralité de perspectives pratiques et théoriques qui ne peuvent être simplement distinguées en termes d'écoféminisme spirituel et essentialiste ou politique et anti-essentialiste. Il faut surtout, comme le rappelle Holmes, dans son analyse de l'écoféminisme chicana, éviter de réintégrer des paradigmes oppressifs dans les généalogies de l'écoféminisme en présentant certaines formes d'écoféminismes comme étant plus «évoluées » que d'autres dès lors qu'elles s'éloignent des dimensions spirituelles, biologiques et naturelles de nos existences pour se concentrer sur les dimensions politiques, sociales et économiques.

Les « devenirs écoféministes » peuvent être retracés à la fois dans le nouveau matérialisme (Casselot), dans la notion derridienne de carnophallogocentrisme (Burgart Goutal) ou dans la vitalité de «spiritualités décoloniales » qui lient des communautés dépossédées à la nature en forgeant des formes de rapports différents avec le monde (Holmes). Et c'est encore un différent embranchement que poursuit Tola dans son analyse de la figure de Gaïa chez Isabelle Stengers comme d'une nature dont nous devons nous soucier, malgré qu'elle ne soucie pas le moindrement de nous. Selon la philosophe des sciences : «la nature nous intéresse alors que nous n'intéressons pas la nature » (Stengers). 


\section{Works Cited}

ADAMS, Carol J and Gruen, Lori. "Groundwork." Ecofeminism: Feminist Intersections with Other Animals and the Earth. Bloomsbury: New York, 2014. 1-36.

GAARD, Greta. "Misunderstanding Ecofeminism," Z papers 3.1. (1994): 20-24.

STENGERS, Isabelle, «Faire avec Gaïa : pour une culture de la nonsymétrie », Multitudes, $\mathrm{n}^{\circ} 24$, printemps 2006. 